\title{
Genetic Variability in Chilli (Byadagi Kaddi) Genotypes
}

\author{
V. Jayasree $^{1 *}$, T. B. Allolli ${ }^{2}$, Shashikanth Evoor ${ }^{1}$, Vasant M. Ganiger ${ }^{1}$, \\ Jnaneshwar B. Gopali ${ }^{3}$ and R. C. Jagadeesh ${ }^{4}$
}

${ }^{1}$ Department of Vegetable Science, University of horticultural Sciences Bagalkot, Karnataka, India

${ }^{2}$ CHEFT, Devihosur, University of horticultural Sciences Bagalkot, Karnataka, India

${ }^{3}$ Department of Entomology, University of horticultural Sciences Bagalkot, Karnataka, India

${ }^{4}$ Department of Biotechnology and Crop Improvement, University of horticultural Sciences

Bagalkot, Karnataka, India

*Corresponding author

\section{A B S T R A C T}

\section{Key w o r ds \\ Chilli, Spice, Condiment, \\ Medicine, Ornamental plants \\ Article Info \\ Accepted: \\ 24 September 2018 \\ Available Online: \\ 10 October 2018}

Genetic variability, heritability and genetic advance as percent of mean for 12 characters were assessed by field evalution observed for all the characters considered for the study. The analysis of variance indicated presence of significant variability among the genotypes for all the characters. Moderate GCV and higher PCV values indicated presence of substantial genetic variability and less environmental influence for average dry fruit weight, dry fruit yield per plant, and capsaicin content. High heritability coupled with high genetic advance as per cent mean were noticed for dry fruit yield per plant, and capsaicin content, suggesting presence of additive gene action for inheritance of these yield attributes. Hence, simple selection would be effective for improvement of these traits.

\section{Introduction}

Chilli has diverse uses as spice, condiment, culinary supplement and medicine, vegetable and ornamental plant. Byadagi chilli is one such variant, predominantly appears across Dharwad, Gadag and Haveri districts of Karnataka. Byadagi chilli known for its quality attributes like colour, flavour and mild pungency. Byadagi chilli is one such genotype or land race more predominantly grown in northern Karnataka. Now there are two important cultivars namely Byadagi dabbi and kaddi, which are being grown presently.
Because of continues cultivation of Byadagi kaddi, several variants have been reported as evident from several reports. Hence evaluation of chilli lines (Byadagi Kaddi) is necessary with respect to morphological descriptors like plant height, plant spread, fruit length and fruit yield characteristics are consistently used to distinguish chilli genotypes.

The phenotypic expression of the plant character is mainly controlled by the genetic makeup of the plant character and the environment in which it is grown as well as the interaction between the genotype and 
environment. Further, the genotype of the plant is controlled by different gene action, i.e., additive gene effect (heritable) and epistatis (non-allelic interaction). It is necessary to partition the observed phenotypic variability into its heritable and non-heritable component with suitable parameter, such as phenotypic and genotypic coefficient of variation, heritability and genetic advance.

\section{Materials and Methods}

The experiment was conducted at Haveli form of college of horticulture during Kharif 20172018 Bagalkot which comes under the zone-3 of region-2 among the agro climatic zones of Karnataka has benefits of both South-West and North-East monsoons. The average rainfall of South-West monsoon is $360 \mathrm{~mm}$, distributed over a period of four months (June to September) with 25 rainy days. The average rainfall of North-East monsoon is $136 \mathrm{~mm}$ with 8 rainy days. During the experimental period, the meteorological data were recorded at the meteorological observatory of Main Horticultural Research and Extension Centre, UHS, Bagalkot. The experiment comprised 48 genotypes of (Byadagi kaddi) chilli collected from HREC Devihosur. Thirty three days old seedlings were transplanted at a spacing of 60 $\mathrm{cm} \times 60 \mathrm{~cm}$ in randomized complete design with two replications. Observations were recorded from five randomly selected plants in each experimental plot for growth, yield and quality parameters. The estimates of genotypic and phenotypic coefficient of variation were calculated according to Burton and Devane (1953), heritability in broad sense (Falconer, 1981) and expected genetic advance as per the procedure of Johnson et al., (1955)

\section{Results and Discussion}

Analysis of variance revealed the significant differences among genotypes for all the traits studied indicating the presence of sufficient genetic variability to be exploited in a breeding programme (Table 1).

Table.1 Analysis of variance for various characters in Chilli (mean sum of squares)

\begin{tabular}{|c|c|c|c|}
\hline \multirow[t]{2}{*}{ Sl. No. } & \multirow[t]{2}{*}{ Character /Source } & \multicolumn{2}{|c|}{ Mean sum of squares } \\
\hline & & Genotype d.f=47 & Error d.f $=47$ \\
\hline 1 & Plant height 60 days & $52.02 *$ & 29.93 \\
\hline 2 & Plant height 90 days & $65.41 * *$ & 32.08 \\
\hline 3 & Plant height 120 days & $93.08 * *$ & 25.84 \\
\hline 4 & Number of primary branches & $0.50 *$ & 0.290 \\
\hline 5 & Number of secondary branches & $0.289 *$ & 0.17 \\
\hline 6 & Plant Spread @ 60 days E-W & $48.36^{*}$ & 29.68 \\
\hline 7 & Plant Spread @60 days N-S & $51.57 * *$ & 24.01 \\
\hline 8 & Plant Spread @90 days E-W & $54.73 * *$ & 28.90 \\
\hline 9 & Plant Spread@90 days N-S & $47.52 * *$ & 27.72 \\
\hline 10 & Plant Spread@120 days E-W & $49.34 * *$ & 27.48 \\
\hline 11 & Plant Spread@120 days N-S & $59.12 * *$ & 29.19 \\
\hline 12 & Fruit length(cm) & $2.72 *$ & 0.691 \\
\hline 13 & Fruit diameter(mm) & $0.92 * *$ & 0.108 \\
\hline 14 & Number of fruits per plant & $31.70 * *$ & 4.91 \\
\hline 15 & Average dry fruit weight $(\mathrm{g})$ & $0.04 * *$ & 0.015 \\
\hline 16 & Dry fruit yield per plant (g) & $135.61 * *$ & 31.61 \\
\hline 17 & Fruit yield per plot(kg) & $0.10 *$ & 0.0089 \\
\hline 18 & Dry fruit yield per plot $(\mathrm{q} / \mathrm{ha})$ & $10.43 * *$ & 2.43 \\
\hline 19 & Ascorbic acid (mg/100g) & $714.90 * *$ & 4.70 \\
\hline 20 & Capsaicin (SHU) & $3666527.16^{* *}$ & 1456295.44 \\
\hline
\end{tabular}

d.f $=$ Degrees of freedom 
Table.2 Estimates of mean, range, components of variance, heritability, and genetic advance for growth, yield and Quality parameters in chilli

\begin{tabular}{|c|c|c|c|c|c|c|c|c|c|c|c|c|}
\hline \multirow{2}{*}{$\begin{array}{l}\text { Sl. } \\
\text { No. }\end{array}$} & \multirow{2}{*}{\multicolumn{2}{|c|}{ Character }} & \multirow{2}{*}{$\begin{array}{l}\text { Grand } \\
\text { Mean }\end{array}$} & \multicolumn{2}{|c|}{ Range } & \multirow[t]{2}{*}{$\mathbf{G V}$} & \multirow[t]{2}{*}{ PV } & \multirow{2}{*}{$\begin{array}{l}\text { GCV } \\
(\%)\end{array}$} & \multirow{2}{*}{$\begin{array}{l}\text { PCV } \\
(\%)\end{array}$} & \multirow{2}{*}{$\begin{array}{c}\text { h2 } \\
(\%) \\
(\text { BS) }\end{array}$} & \multirow[t]{2}{*}{ GA } & \multirow{2}{*}{$\begin{array}{c}\text { GAM } \\
(\%)\end{array}$} \\
\hline & & & & Min. & Max. & & & & & & & \\
\hline \multirow[t]{3}{*}{1} & \multirow{3}{*}{$\begin{array}{l}\text { Plant height } \\
(\mathrm{cm})\end{array}$} & 60 DAT & 60.10 & 45.25 & 69.05 & 11.04 & 40.97 & 5.53 & 10.65 & 27.00 & 3.55 & 5.91 \\
\hline & & 90 DAT & 68.82 & 57.60 & 75.80 & 16.66 & 48.75 & 5.93 & 10.14 & 34.20 & 4.91 & 7.14 \\
\hline & & 120 DAT & 71.45 & 59.85 & 93.75 & 33.61 & 59.46 & 8.11 & 10.79 & 56.50 & 8.98 & 12.56 \\
\hline \multirow[t]{6}{*}{2} & \multirow[t]{6}{*}{$\begin{array}{l}\text { Plant spread } \\
(\mathrm{cm})\end{array}$} & $\begin{array}{c}(\mathrm{E}-\mathrm{W}) 60 \\
\text { DAT }\end{array}$ & 40.80 & 30.85 & 50.90 & 10.94 & 40.62 & 8.10 & 15.62 & 26.90 & 3.53 & 8.67 \\
\hline & & $(\mathrm{N}-\mathrm{S}) 60$ DAT & 40.27 & 31.10 & 53.20 & 12.17 & 36.18 & 8.66 & 14.93 & 33.60 & 4.16 & 10.35 \\
\hline & & $\begin{array}{l}(\mathrm{E}-\mathrm{W}) 90 \\
\text { DAT }\end{array}$ & 49.60 & 40.45 & 62.65 & 12.91 & 41.82 & 7.24 & 13.03 & 30.90 & 4.11 & 8.18 \\
\hline & & (N-S)90 DAT & 47.79 & 39.60 & 58.15 & 9.89 & 37.62 & 6.58 & 12.83 & 26.30 & 3.32 & 6.95 \\
\hline & & $\begin{array}{c}(\mathrm{E}-\mathrm{W}) \mathbf{1 2 0} \\
\text { DAT }\end{array}$ & 49.78 & 42.05 & 71.60 & 10.93 & 38.41 & 6.59 & 12.44 & 28.50 & 3.58 & 7.20 \\
\hline & & $\begin{array}{l}\text { (N-S) } 120 \\
\text { DAT }\end{array}$ & 50.21 & 40.20 & 65.40 & 14.96 & 44.16 & 7.66 & 13.25 & 33.91 & 4.63 & 9.22 \\
\hline 3 & \multicolumn{2}{|c|}{ Primary branches } & 4.51 & 3.70 & 5.80 & 0.10 & 0.39 & 7.66 & 13.25 & 27.20 & 0.35 & 7.84 \\
\hline 4 & \multicolumn{2}{|c|}{ Secondary branches } & 5.93 & 4.95 & 6.80 & 0.05 & 0.23 & 3.97 & 8.14 & 23.80 & 0.23 & 4.00 \\
\hline 5 & \multicolumn{2}{|c|}{ Fruit length(cm) } & 13.62 & 9.25 & 15.60 & 1.01 & 1.70 & 7.39 & 9.59 & 59.50 & 1.60 & 11.74 \\
\hline 6 & \multicolumn{2}{|c|}{ Fruit diameter(mm) } & 5.05 & 3.45 & 6.50 & 0.40 & 0.51 & 12.62 & 14.21 & 78.90 & 1.16 & 23.11 \\
\hline 7 & \multicolumn{2}{|c|}{ Number of fruits per plant } & 42.80 & 34.50 & 53.25 & 13.39 & 18.31 & 8.54 & 9.99 & 73.10 & 6.44 & 15.05 \\
\hline 8 & \multicolumn{2}{|c|}{ Average dry fruit weight(g) } & 0.88 & 0.50 & 1.21 & 0.01 & 0.03 & 14.15 & 20.13 & 49.40 & 0.18 & 20.49 \\
\hline 9 & \multicolumn{2}{|c|}{ Dry fruit yield per plant (g) } & 37.83 & 20.25 & 56.69 & 52.00 & 83.61 & 19.05 & 24.16 & 62.20 & 11.71 & 30.96 \\
\hline 10 & \multicolumn{2}{|c|}{$\begin{array}{l}\text { Dry fruit yield per } \\
\operatorname{plot}(q / h a)\end{array}$} & 10.45 & 5.60 & 15.70 & 4.001 & 6.43 & 19.12 & 24.25 & 62.2 & 3.24 & 31.06 \\
\hline 11 & \multicolumn{2}{|c|}{ Ascorbic acid(mg/100g) } & 126.07 & 97.25 & 172.90 & 355.10 & 359.80 & 14.94 & 15.04 & 98.70 & 38.56 & 30.58 \\
\hline 12 & \multicolumn{2}{|c|}{ Capsaicin(SHU) } & 6827.1 & 4087.5 & 10230.5 & 1105116.0 & 256141.0 & 15.39 & 23.44 & 43.10 & 1422.4 & 20.83 \\
\hline
\end{tabular}

$\mathrm{PV}=$ Phenotypic variance; $\mathrm{GA}=$ Expected genetic advance; $\mathrm{PCV}=$ Phenotypic coefficient of variation; $\mathrm{GAM}=\mathrm{Genetic}$ advance as percentage over mean; $\mathrm{GV}=$ Genotypic variance; GCV = Genotypic coefficient of variation; h2 = Heritability (broad sense) 
The wide range of variation was observed for all the 12 characters (Table 2). A better idea can be gained by comparing the relative amount of phenotypic and genotypic coefficient variance for the actual strength of variability. The GCV ranged from 3.97 percent (Secondary branches) 19.12 percent (Dry fruit yield per plot). The relative magnitude of GCV and PCV when compared, indicated that the PCV values were greater than the GCV values in respective of all the characters under observation and the differences between PCV and GCV were quite less, indicating additive effect of the environment on the expression of trait. High estimates of GCV were observed for dry fruit yield per plot (19.12\%) followed by dry fruit yield per plant $(19.05 \%)$ indicating that the selection for these characters would be effective. For capsaicin and ascorbic acid GCV and PCV values were moderate (Manju and Sreelathakumary, 2002; Chaudhary et al., 2013; Singh et al., 2005).

Higher estimates of heritability (broad sense) values were observed for all the 12 characters. The heritability estimated range from $(23 \%)$ for secondary branches to (98\%) for capsaicin. High heritability is an indication of presence of higher proportion of fixable additive variance in the population. Heritability value is of much use to breeder as indicates the accuracy with which a genotype can be evaluated by its phenotypic expression and these findings are consonance with the results obtained by earlier works (Manju and Sreelathakumary, 2008; Munshi et al., 2010 and Datta and Das, 2013). The genetic advance as percent of mean was highest for the dry fruit yield per plot $(31.06 \%)$ followed by dry fruit yield per plant $(30.96 \%)$ and ascorbic acid (30.58\%). Heritability estimates together with genetic advance provide better response during selection than either of the parameters alone. In the present study, high genetic advance coupled with heritability was obtained for all yield and quality related characters, indicating pure line selection or individual plant selection could be effectively utilized for isolation of superior genotypes for these traits. Traits with high heritability and moderate genetic advance viz., number of fruits per plant was governed by additive genes and could be equally improved through selection.

\section{References}

Abdul Razzaq, Tariq Manzoor Khan, Asif Saeed, Sohail Kamaran, AlamZeb., 2016 Genetic diversity and association analysis for different morphological traits in (Capsicum annum) Int. J. Biomol. Biomed. 5 (1) pp: 20-28.

Burton, G. W. and Devane, E. M., 1953, Estimating heritability in tall Fescue (Festuca arunidinacea) from replicated clonal material. Agron. J., 45:478-481.

Chaudhary, A., Kumar, R. and Solankey, S. S., 2013, Estimation of heterosis for yield and quality components in chilli (Capsicum annuum L.). African J. Biotech., 12 (47): 6605-6610.

Datta, S. and Das, L., 2013, Characterization and genetic variability analysis in Capsicum annuum L. germplasm. SAARC J. Agri., 11 (1): 91-103.

Falconer, D. S., 1981, Introduction to Quantitative Genetics, 2nd edition, Longma Group Ltd., Longman House, Harrow, England, p. 350.

Johnson, H. W., Robinson, H. F. and Comstock, R. E., 1955, Genotypic and phenotypic correlations in soybean and their implications in selection. Agron. J., 37: 477-483.

Lakshmi, S. L and Sreelathakumary, I., 2016, Evaluation of paprika (Capsicum annuum L.) accessions for capsaicin content and pungency. Imperial $J$. Interdisciplinary Res., 4 (2): 702-704. 
Manju, P. R and Sreelathakumary, I., 2007, Quality parameters in hot chilli (Capsicum chinense JACQ.) $J$. Tropical, Agri., pp. 7-10.

Manju, P. R. and Sreelathakumary, I., 2002, Genetic variability, heritability and genetic advance in hot chilli (Capsicum chinense L). J. Tropical Agri., 40: 4-6.

Munshi, A. D., Kumar, B. K., Sureja, A. K. and Joshi, S., 2010, Genetic variability, heritability and genetic advance for growth, yield and quality traits in chilli. Indian J. Hort., 67 (1): 114-116.
Singh, H., Suboth Srivastava and Singh, A. K., 2005, Path analysis of component traits of yield in chilli (Capsicum annuит L.). Prog. Hort., 37 (2): 377384.

Vijaya, H. M., Mallikarjunagowda, A. P. and Nehru, S. D., Lingaiah, H. B. and Umesha. K., 2014, Variability, heritability and genetic advance for growth, yield and quality in chilli (Capsicum annum L). Annals of Agri Bio Research., 19 (2): 298-300.

\section{How to cite this article:}

Jayasree, V., T.B. Allolli, Shashikanth Evoor, Vasant M. Ganiger, Jnaneshwar B. Gopali and Jagadeesh, R.C. 2018. Genetic Variability in Chilli (Byadagi Kaddi) Genotypes. Int.J.Curr.Microbiol.App.Sci. 7(10): 3532-3536. doi: https://doi.org/10.20546/ijcmas.2018.710.408 